Editorial

\title{
Editorial: “Complex Religion: Intersections of Religion and Inequality"
}

\author{
Melissa J. Wilde \\ Department of Sociology, University of Pennsylvania, Philadelphia, PA 19104, USA; E-Mail: mwilde@sas.upenn.edu
}

Submitted: 8 June 2018 | Published: 22 June 2018

\begin{abstract}
What is complex religion and how does it relate to social inclusion? Complex religion is a theory which posits that religion intersects with inequality, especially class, race, ethnicity and gender. The nine articles in this volume examine a wide array of ways that religion intersects with inequality, and how, as a result, it can create barriers to social inclusion. The issue begins with three articles that examine the role of religion and its intersection with race and racialization processes. It then moves to three articles that examine religion's intersection with socioeconomic inequality. The issue closes with three studies of how religion's relationship with the state creates and maintains various status hierarchies, even as some religious movements seek to combat inequality. Together, these articles enrichen our understanding of the complex task before anyone seeking to think about the role of religion in social inclusion.
\end{abstract}

\section{Keywords}

class; complex religion; gender; inequality; intersectionality; Islam; race; racialization; religion

\section{Issue}

This editorial is part of the issue "Complex Religion: Intersections of Religion and Inequality", edited by Melissa J. Wilde (University of Pennsylvania, USA).

(C) 2018 by the author; licensee Cogitatio (Lisbon, Portugal). This article is licensed under a Creative Commons Attribution 4.0 International License (CC BY).

\section{Introduction}

What is complex religion and how does it relate to social inclusion? Complex religion is a theoretical stance that comes with corresponding methodical decisions. At its most basic level, the theory argues that religion intersects with inequality, especially class, race, ethnicity and gender (Wilde \& Glassman, 2016; Wilde \& Tevington, 2017). Because some of these intersections are quite robust, complex religion theory argues that religion should almost always be examined in interaction with these social structures (Wilde, 2017). The term complex religion builds on theories of complex inequality, which argue that social stratification is multidimensional (Choo \& Ferree, 2010; McCall, 2001). Complex religion extends these theories to include religious group membership among the social structures that matter for inequality, as it also brings inequality into focus for researchers who are mainly interested in religion.

The nine articles in this volume examine a wide array of ways that religion intersects with inequality, and how, as a result, it can create barriers to social inclusion. These articles examine religion both in the US and abroad. They examine its relationship with common measures of inequality, such as socioeconomic resources and educational attainment (Wilde, Tevington, \& Shen, 2018). They examine how those structures relate to decisions about how to help fellow church members who are in need (Glassman, 2018), how to engage in political activism (Sager, 2018), and even when to marry (Tevington, 2018). The articles in this volume examine how "reasonable accommodation" of religious differences can result in living well-or poorly-together (Barras, Selby, \& Beaman, 2018). They do so by examining tensions between nativeborn African-American Muslims and their wealthier, immigrant religious brothers and sisters-in the mosque (Prickett, 2018) and in religious schools (Guhin, 2018). They do so by examining the relationship between education and employment among Muslims in Sweden (Lindemann, \& Stolz, 2018). The articles in this volume even examine how religion can reproduce inequality behind prison walls (Ellis, 2018).

I have grouped these articles by the type of social inequality - of social inclusion and exclusion-each one is 
focused on. The issue begins with three articles that examine the role of religion and its intersection with race and racialization processes. It then moves to three articles that examine religion's intersection with socioeconomic inequality. The issue closes with three studies of how religion's relationship with the state creates and maintains various status hierarchies, even as some religious movements seek to combat inequality. This is not to say, however, that any one of these articles examines only one way that religion intersects with other social structures. Almost all of them acknowledge the multiple, competing, and thoroughly complex ways that religious intersects with various other structures of inequality or social life, even as they focus, as they must, mainly on one of these.

Together, these articles enrichen our understanding of the complex task before anyone seeking to think about the role of religion in social inclusion.

\section{Intersections of Religion and Race: Islam and Racialization}

Sociologists have long acknowledged that religion plays a crucial role in racialization processes. In the words of theorists of racialization processes, religion is a critical dimension upon which race is "culturally figured and represented, the manner in which race comes to be meaningful as a descriptor of group or individual identity, social issues, and experience" (Winant, 1998, p. 756). As Catholicism and Judaism were racialized a century ago in the US (see Wilde \& Danielsen, 2015), today the key racialization process that is occurring vis a vis religion in the US and other industrialized countries has to do with Islam. To that end, we are treated with three articles in this volume that examine various disadvantages faced by Muslims in the US and in Europe.

By engaging the growing body of literature on the racialization of Muslim immigrants and exploring his own data from an ethnographic study of an immigrant Muslim high school, Jeffrey Guhin argues that "American Islam is only sociologically intelligible through its intersections with other salient identities especially...race and ethnicity" (Guhin, 2018, p. 87).

Pamela Pricket's study of an African-American mosque in South Central Los Angles also examines how American Islam intersects with race, particularly in her nuanced account of the tensions that exist between the African-American members and Arab immigrant Muslim neighbors. Pricket explicitly connects these tensions to the divergent class locations of the two groups, pointing out vividly how those differences are felt when the wealthier Muslims bring her respondents gifts of charity during Ramadan. She thus concludes that "the ways in which American Muslims experience stigma and inequality varies depending on how their religious identification intersects with other dimensions of social stratification (Pricket, 2018, p. 98)."

Anaïd Lindemann and Jörg Stolz find that both the most and least educated Muslims in Sweden experience disproportionately greater unemployment. Acknowledging that it is difficult to distinguish between ethnic and religious discrimination in their case, they conclude that solutions to the Muslim employment gap are not simple. Given that Swedish Muslims with the greatest amounts of human capital experience comparable rates of unemployment as those with the least, their research provides a useful caution to policy makers.

\section{Intersections of Religion and Class Inequality}

Although the study of religion and inequality was marginalized for years because of assumptions that religious inequality was "smaller than [it] used to be and...getting smaller all of the time" (Pyle \& Davidson, 2014 , p. 195), there has been a revival of studies of both the causes and consequences of religious inequality. My article with Patricia Tevington and Wensong Shen describes the current state of religious inequality in the United States in order to make one important point: religious inequality remains. It is profound and robust (Wilde et al., 2018).

Lindsay Glassman's article examines how economic inequality is managed within a tightknit religious group that rejects almost all modern forms of economic advancement, including higher education, health insurance, mortgages and credit cards. She finds that members at Full Truth Church are able to help fellow members, but to do anonymously, by using the Church's resources. In doing so, members are able to thank God for various godsends, and not individuals who are likely better off financially.

By probing reactions to her Evangelical respondents' early marriages, Patricia Tevington finds that while all Evangelicals receive social sanctioning for early marriage, those from middle class backgrounds experience greater stigma, especially from their families, than those from working class or poor backgrounds.

\section{Intersections of Religion and the State}

From theories that argue that state regulation or support of religion creates lazy monopolies (Finke \& Stark, 1992) to studies of how state regulation interacts with other factors like religious diversity (Wilde, 2007; Wilde, Geraty, Nelson, \& Bowman, 2010), religion's relationship with the state has been an important part of the sociology of religion for a long time. Three articles in this issue examine the complexities that emerge from various forms of that relationship, even in societies where disestablishment is par for the course.

Amelie Barras, Jennifer Selby and Lori Beaman show how Canada's mandate of "reasonable accommodation" does little to unseat the power and privilege enjoyed by religious majorities, but seems to, at the same time, cause much religious conflict and especially anti-Muslim sentiment. As such, their article is a powerful example of how religion is "intertwined both with other social cate- 
gories such as ethnicity and class and with social inequality" (Barras et al., 2018, p. 163).

Sometimes, religious institutions can try to change what they see as unfair systems. Rebecca Sager's article examines when and how religious institutions get involved in political organizing to combat inequality. She demonstrates that religious institutions that want to engage in such work often have to work around members who prefer to not get entangled in political disputes (Sager, 2018).

Finally, Rachel Ellis' ethnographic study of religion in a women's prison, highlights how race, class, ethnicity and gender all intersect with the messages female prisoners receive from religious volunteers. She profoundly points out the contradiction between Conservative Protestant messages about finding "Godly men," and the reality of the marriage markets that female prisoners will return to if-and when-they are released. As she puts it so eloquently: "The environment in which adherents "do religion" exists within a broader landscape of stratification" (Ellis, 2018, p. 183).

\section{Conclusion}

In sum, the articles in this thematic issue examine many aspects of religion's intersection with inequalitywhether race and racialization processes, class and economic differences, or attempts to administer or change some aspect of state laws as they relate to religion. That said, although the variety, depth and insightfulness of the articles presented in this issue are impressive, in some sense, they represent only the very beginning of the possible theoretical and empirical rewards that can come from employing an intersectional approach to the study of religion. I close this introduction hoping that these articles will spark many more.

\section{Conflict of Interests}

The author declares no conflict of interests.

\section{Acknowledgements}

This issue has been made possible by the Program for Research on Religion and Urban Civil Society at the University of Pennsylvania.

\section{References}

Barras, A., Selby, J., \& Beaman, L. (2018). Rethinking Canadian discourses of "reasonable accommodation". Social Inclusion, 6(2), 162-172.

Choo, H. Y., \& Ferree, M. M. (2010). Practicing intersectionality in sociological research: A Critical analysis of inclusions, interactions, and institutions in the study of inequalities. Sociological Theory, 28(2), 129-149. https://doi.org/10.1111/j.1467-9558.2010.01370.x

Ellis, R. (2018). "It's not equality": How race, class, and gender construct the normative religious self among female prisoners. Social Inclusion, 6(2), 181-191.

Finke, R., \& Stark, R. (1992). The churching of America, 1776-2005: Winners and losers in our religious economy. New Brunswick: Rutgers University Press.

Glassman, L. (2018). "You help them out and God gets the glory": Social class and inequality in a fundamentalist Christian church. Social Inclusion, 6(2), 127-139.

Guhin, J. (2018). Colorblind Islam: The racial hinges of immigrant Muslims in the United States. Social Inclusion, 6(2), 87-97.

Lindemann, A., \& Stolz, J. (2018). The Muslim employment gap, human capital, and ethno-religious penalties: Evidence from Switzerland. Social Inclusion, 6(2), 151-161.

McCall, L. (2001). Complex inequality: Gender, class and race in the new economy (1st ed.). New York, NY: Routledge.

Prickett, P. (2018). Complexity beyond intersections: Race, class, and neighborhood disadvantage among African American Muslims. Social Inclusion, 6(2), 98-106.

Pyle, R. E., \& Davidson, J. D. (2014). Social reproduction and religious stratification. In L. A. Keister \& D. E. Sherkat (Eds.), Religion and inequality in America (pp. 195-218). New York, NY: Cambridge University Press.

Sager, R. (2018). Systems over service: Changing systems of inequality through congregational political engagement. Social Inclusion, 6(2), 173-180.

Tevington, P. (2018). "You're throwing your life away": Sanctioning of early marital timelines by religion and social class. Social Inclusion, 6(2), 140-150.

Wilde, M. J. (2007). Vatican II: A sociological analysis of religious change. Princeton, NJ: Princeton University Press.

Wilde, M. J. (2017). Complex religion: Interrogating assumptions of independence in the study of religion. Sociology of Religion, srx047. https://doi.org/ 10.1093/socrel/srx047

Wilde, M. J., \& Danielsen, S. (2014). Fewer and better children: Race, class, religion, and birth control reform in America. American Journal of Sociology, 119(6), 1710-1760. https://doi.org/10.1086/674007

Wilde, M. J., Geraty, K., Nelson, S., \& Bowman, E. (2010). "Religious economy or organizational field? Predicting bishops' votes at the second Vatican council." American Sociological Review, 75(4), 586-606.

Wilde, M. J., \& Glassman, L. (2016). How complex religion can help us understand politics in America. Annual Review of Sociology, 42(1). https://doi.org/ 10.1146/annurev-soc-081715-074420

Wilde, M. J., Pilgrim, H., \& Shen, W. (2017). Blackness as primacy: The continuing significance of race for black American's political views. Paper presented at the Association for the Sociology of Religion and American Sociological Association, Montreal, Canada.

Wilde, M. J., \& Tevington, P. (2017). Complex reli- 
gion: Toward a better understanding of the ways in which religion intersects with inequality. In R. A. Scott \& M. C. Buchmann (Eds.), Emerging trends in the social and behavioral sciences: An interdisciplinary, searchable, and linkable resource (pp. 1-14). Hoboken, NJ: John Wiley \& Sons, Inc. https://doi.org/10.1002/9781118900772.etrds0440

Wilde, M., Tevington, P., \& Shen, W. (2018). Religious inequality in America. Social Inclusion, 6(2), 107-126.

Winant, H. (1998). "Racism today: Continuity and change in the post-civil rights era". Ethnic and Racial Studies, 21(4), 755-766.

\section{About the Author}

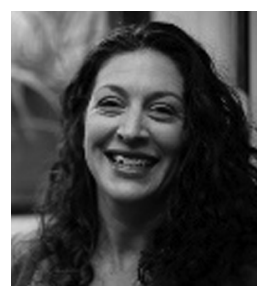

Melissa J. Wilde (PhD in Sociology, 2002, from UC Berkeley) is an Associate Professor at the University of Pennsylvania. Most of her research has focused on religious change, including: the cultural and organizational factors behind Vatican II; the demographic factors that explain why American Protestantism has gone from being majority Mainline to majority conservative; and how race and class intersected with American religious groups to explain early stances on birth control. Lately, her research has become focused on how certain qualities of the American religious field, especially inequality, haven't changed, and how those enduring features of American religion can help us understand religious views of sex, poverty, and even politics today. 